fauna as elsewhere, each species varying within its definite range as each species appears to bave varied at all times past and present" (p. 50).

Exactly so; the abyssal species are like species elsewhere. The difficulties in the way of the application of the evolution of species by variation and selection therefore in this case cannot be greater than elewhere. In fact, from the sentences which end the "Introduction" it seems doubtful whether they are not less than in many other cases.

"Transition forms linking species so closely as to cause a doubt as to their limit are rarely met with. There is usually no difficulty in telling what a thing is" (p. 50).

Hence it appears that the study of the abyssal fauna has satisfied Sir Wyville Thomson that transitional forms are sometimes met with; and that, sometimes, he has found a difficulty in "telling what a thing is." And this admission is all that the most ardent disciple of Mr. Darwin could desire.

However, the value of the great work which is now being brought before the public does not lie in the speculations which may be based upon it, but in the mass and the solidity of the permanent additions which it makes to our knowledge of natural fact. Sir Wyville Thomson and his colleagues must be congratulated on having made an excellent beginning; the looker-on may properly content himself with wishing them a speedy and a good ending.

T. H. HUXLEY

\section{THE LAVA-FIELDS OF NORTH-WESTERN EUROPE}

$\mathrm{F}$ ROM the earliest times of human tradition the basin of the Mediterranean has been the region from which our ideas of volcanoes and volcanic action have been derived. When the old classical mythology passed away and men began to form a more intelligent conception of a nether region of fire, it was from the burning mountains of that basin that the facts were derived which infant philosophy sought to explain. Pindar sang of the crimson floods of fire that rolled down from the summit of Etna to the sea as the buried Typhoeus struggled under his mountain load. Strabo, with matter-of-fact precision and praiseworthy accuracy, described the eruptions of Sicily and the Aeolian Islands, and pointed out that Vesuvius, though it had never been known as an active volcano, yet bore unequivocal marks of having once been corroded by fires that had eventually died out from want of fuel. In later centuries, as the circle of human knowledge and experience has widened, it has still been by the Mediterranean type that the volcanic phenomena of other countries have been judged. When a geologist thinks or writes of volcanoes and volcanic action, it is the structure and products of such mountains as Etna and Vesuvius that are present to his mind. Nowhere over the whole surface of the globe have eruptions been witnessed different in kind though varying in degree from those of the Mediterranean vents. And hence even among those who have specially devoted themselves to the study of volcanoes there has been a tacit assumption that from the earliest times and in all countries of the world where volcanic outbreaks have occurred, it has been from local vents like those of Etna, the Aeolian Islands, the Phlegraean Fields, or the Greek Archipelago.
If one were to assert that this assumption is probably erroneous, that the type of volcanic "cones and craters" has not been in every geological age and all over the earth's surface the prevalent one, that, on the contrary, it is the less portentous, though possibly always the most frequent type of volcanic action, and belongs perhaps to a feebler or waning degree of volcanic excitement-these statements would be received by most European geologists with incredulity, if not with some more pronounced form of dissent. Yet I am convinced that they are well founded, and that a striking illustration of their truth is supplied by the greatest of all the episodes in the volcanic history of Europe-that of the basalt-plateaux of the north-west.

It is now some twelve years since Richthofen pointed out that on the Pacific slope of North America there is evidence of the emission of vast floods of lava without the formation of cones and craters. Geologists interested in these matters may remember with what destructive energy Scrope reviewed his " Natural System of Volcanic Rocks"; how he likened it to the old crude ideas that had been in vogue in his younger days, and which a study of the classical district of Auvergne had done so much to dispel; and how he ridiculed what he regarded as "fanciful ideas" and "untenable distinctions," which it was "a miserable thing" to find still taught in miningschools abroad. My own reverence for the teaching of so eminent a master and so warm-hearted a friend led me to acquiesce without question in the dictum of the author of "Considerations on Volcanoes." Having rambled over Auvergne with his admirable sections and descriptions in my hand, I knew his contention as to the removal of cones and craters by denudation and the survival of more or less fragmentary plateaux once connected with true cones to be undoubtedly correct with respect at least to that region. Nevertheless there were features of former volcanic action on which the phenomena of modern volcanoes seemed to me to throw very little light. In particular the vast number of fissures which in Britain had been filled with basalt and now formed the well-known and abundant "dykes" appeared hardly to connect themselves with any known phase of volcanism. The area over which these dykes can be traced is probably not less than I00,000 square miles, for they occur from Yorkshire to Orkney, and from Donegal to the mouth of the Tay. As they pierce formations of every age, including the Chalk, as they traverse even the largest faults and cross from one group of rocks into another without interruption or defiection, as they become more numerous towards the great basaltic plateaux of Antrim and the Inner Hebrides, and as they penetrate the older portions of these plate 4 ux, I inferred that the dykes probably belonged to the great volcanic period which witnessed the outburst of these western basalts. Further research has fully confirmed this inference. There can be no doubt that the outpouring of these great floods of lava of which the hills of Antrim, Mull, Morven, Skye, Faroe, and part of Iceland are merely surviving fragments and the extravasation of these thousands of dykes are connected manifestations of volcanic energy during the Miocene period.

But this association of thin nearly level sheets of basalt piled over each other to a depth of sometimes 3,000 fect, with lava-filled fissures sometimes 200 miles distant from 
them, presented difficulties which in the light of modern volcanic action remained insoluble. The wonderfully persistent course and horizontality of the basalts with the absence or paucity of interstratified tuffs, and the want of any satisfactory evidence of the thickening and uprise of the basalts towards what might be supposed to be the vents of eruption were problems which again and again I attempted vainly to solve. Nor so long as the incubus of "cones and craters" lies upon one's mind does the question admit of an answer. A recent journey in Western America has at last lifted the mist from my geological vision. Having travelled for many leagues over some of the lava-fields of the Pacific slope, I have been enabled to realise the conditions of volcanism described by Richthofen and, without acquiescing in all his theoretical conclusions, to judge of the reality of the distinction which he rightly drew between "massive eruptions" and ordinary volcanoes with cones and craters. Never shall I forget an afternoon in the autumn of last year upon the great Snake River lava desert of Idaho. It was the last day of a journey of several hundred miles through the volcanic region of the Yellowstone and Madison. We had been riding for two days over fields of basalt, level as lake bottoms, among the valleys, and on the morning of the last day, after an interview with an armed party of Indians (it was only a few days before the disastrous expedition of Major Thornburgh, and the surrounding tribes were said to be already in a ferment), we emerged from the mountains upon the great sea of black lava which seems to stretch illimitably westwards. With minds keenly excited by the incidents of the journey, we rode for hours by the side of that apparently boundless plain. Here and there a trachytic spur projected from the hills, succeeded now and then by a valley up which the black flood of lava would stretch away into the high groundis. It was as if the great plain had been filled with molten rock which had kept its level and wound in and out along the bays and promontories of the mountain-slopes as a sheet of water would have done. Copious springs and streams which issue from the mountains are soon lost under the arid basalt. The Snake River itself, however, has cut out a deep gorge through the basalt down into the trachytic lavas underneath, but winds through the desert without watering it. The precipitous walls of the cañon show that the plain is covered by a succession of parallel sheets of basalt to a depth of several hundred feet. Here and there, I was told, streams that have crossed from the hills and have flowed underneath the lava-desert issue at the base of the cañon-walls, and swe!l the Snake River on its way to the Pacific. The resemblance of the horizontal basait-sheets of this region to those with which I was familiar at home brought again vividly before my mind the old problem of our Miocene dykes and Richthofen's rejected type of "massive" or fissure eruptions. I looked round in vain for any central cone from which this great sea of basalt could have flowed. It assuredly had not come from the adjacent mountains, which consisted of older and very different lavas round the worn flanks of which the basalt had eddied. A few solitary cinder cones rose at wide intervals from the basalt plain, as piles of scoriæ sometimes do from the vapour vents on the surface of a Vesuvian lava-stream, and were as unequivocally of secondary origin. Riding hour after hour among these arid wastes, I became convinced that all volcanic phenomena are not to be explained by the ordinary conception of volcanoes, but that there is another and grander type of volcanic action, where, instead of issuing from separate vents and piling up cones of lava and ashes around them, the molten rock has risen in fissures, sometimes accompanied by the discharge of little or no fragmentary material, and has welled forth so as to flood the lower ground with successive horizontal sheets of basalt. Recent renewed examination of the basalt-plateaux and associated dykes in the west of Scotland has assured me that this view of their origin and connection, which first suggested itself to my mind on the lava-plains of Idaho, furnishes the true key to their history.

The date of these lava-floods of the Snake River is in a geological sense quite recent. They have been poured over the bottoms of the present valleys, sealing up beneath their sheets of solid stone river-beds and lake-floors with their layers of gravel and silt. The surface of the lava is in many places black and bare as if it had cooled only a short while ago. Yet there has been time for the excavation of the Snake River cañon to a depth of 700 feet through the basalt-floor of the plain. In so arid a climate, however, the denudation of this floor must be extremely slow. Much of the plain is a verdureless waste of loose sand and dust which has gathered into shifting dunes. Save in the gorges laid open by the main river and some of its tributaries hardly any sections have yet been cut into the volcanic fioor. Dykes and other protrusions of basalt occur on the surrounding hills, but the chief fissures or vents of emission are still no doubt buried beneath the lava that escaped from them.

In North-Western Europe, however, the basalt-sheets were erupted as far back as Miocene times. Since then, exposed to many vicissitudes of geological history-subterranean movement and changes of climate, with the whole epigene army of destructive agencies, air, rain, frost, streams, glaciers, and ice-sheets-the volcanic plateaux, trenched by valleys two or three thousand feet deep and a mile or more in breadth, and stripped bodily off many a square mile of ground over which they once spread, have been so scarped and cleft that their very roots have been laid bare. Viewed in the light of the much younger basalts of the Western Territories of North America, their history becomes at last intelligible and more than ever interesting. We are no longer under the supposed necessity of finding volcanic cones vast enough to have poured forth such wide-spread floods of basalt. The sources of the molten rock are to be sought in those innumerable dykes which run across Britain from sea to sea, and which in this view of their relations at once fall into their place in the volcanic history of the time.

No more stupendous series of volcanic phenomena has yet been discovered in any part of the globe. We are first presented with the fact that the crust of the earth over an area which in the British Islands alone amounted to probably not less than 100,000 square miles, but which was only part of the far more extensive region that included the Faroe Islands and Iceland, was rent by innumerable fissures in a prevalent east and west or southeast and north-west direction. These fissures, whether due 
to sudden shocks or slow disruption, were produced with such irresistible force as to preserve their linear character and parallelism through rocks of the most diverse nature, and even across old dislocations having a throw of many thousand feet. Yet so steadily and equably did the fissuring proceed over this enormous area, that comparatively seldom was there any vertical displacement of the sides. We rarely meet with a fissure which has been made a true fault with an upthrow and downthrow side.

The next feature is the rise of molten basalt up these thousands of fissures. The most voluminous streams of lava that have issued from any modern volcanic cone appear but as a minor manifestation of volcanic activity when compared with the filling of those countless rents over so wide a region. Mining operations in the Scottish coal-fields have shown that dykes do not always reach the surface. In all parts of the country, too, examples may be observed of breaks in the continuity of dykes. The same dyke vanishes for an interval and reappears on the same line, but is doubtless continuous underneath. What proportion of the dykes ever communicated with the surface at the time of their extravasation is a question that may perhaps never be answered. It is difficult to believe that a considerable number of them did not overflow above ground even far to the east of the main and existing outflows. But so extensive has been the subsequent denudation that all trace of such superficial emission has been removed. The general surface of the country has been lowered by sub-aërial waste several hundred feet at least, and the dykes now protrude as hard ribs of rock across the hills.

Traced westwards the dykes increase in abundance, till at last they reach the great basaltic plateaux. Macculloch long ago sketched them in Skye, rising through the Jurassic rocks and merging into the overlying sheets of basalt. Similar sections occur in the other islands and in the north of Ireland. The lofty mural escarpments presented by the basalt plateaux once extended far beyond the limits to which they have now been reduced. The platform from which they have been removed shows in its abundant dykes the fissures up which the successive discharges of lava rose to the surface, where they overflowed in wide level sheets like those still so fresh and little eroded in Western North America.

That there were intervals between successive outpourings of basalt is indicated by the occasional interstratification of seams of coal and shale between the different flows. These partings contain a fragmentary record of the vegetation which grew on the neighbouring hills and which may even have sometimes found a foothold on the crumbling surface of the basalt floor until overwhelmed by fresh floods of lava. Not a trace of marine organisms has anywhere been found among these interstratifications. There is every reason to believe that the volcanic eruptions were all subaërial. Sheet after sheet was poured forth over the wide valley between the mountains of Donegal and the Outer Hebrides on the one side and those of the north-east of Ireland and the west of Scotland on the other, until the original surface had been buried in some places 3000 feet beneath volcanic ejections.

I believe that the most stupendous outpourings of lava in geological history have been effected not by the familiar type of conical volcano, but by these less known fissure-eruptions. Both types are of course only manifestations in different degrees of the same volcanic energy. It is by no means certain that the "massive" or fissure type belongs wholly to former geological periods. In particular one is disposed to inquire whether the great Icelandic lava-floods of 1783 -the most voluminous on record-may not have been connected rather with the opening of widereaching fissures than with the emissions of a single volcanic cone. The reality and importance of the grander phase of volcanism marked by fissure-eruptions have been recognised by some of the able geologists who in recent years have explored the Western States and Territories of the American Union. But they have not yet received due acknowledgment on this side of the Atlantic, where the lesser type of cones and craters has been regarded as that by which all volcanic manifestations must be judged. We are fortunate in possessing in the north-west of Europe so magnificent an example of fissure-eruptions, and one which has been so dissected by denudation that its whole structure can be interpreted. The grand examples on the Pacific slope of America have yet to be worked out in detail, and will no doubt cast much fresh light on the subject, more especially upon those phenomena of which in Europe the traces have been removed by denudation. But the other continents also are not without their illustrations. The basaltic plateaux of Abyssinia and the "Deccan traps" of India probably mark the sites of some of the great fissure-eruptions which have produced the lava-fields of the Old World. In their recent admirable resume of the "Geology of India," Messrs. Medlicott and Blanford describe the persistent horizontality of the vast basalt-sheets of the Deccan, the absence of any associated volcanic cones or the least trace of them in that region, and the abundance of dykes in the underlying platform of older rocks where it emerges from beneath the volcanic plateaux. They confess the difficulty of explaining the origin of such enormaus outpourings of basalt by reference to any modern volcanic phenomena. Their descriptions of these Indian Cretaceous lava-floods might, however, be almost literally applied to the Miocene plateaux of North-western Europe and to the Pliocene or recent examples of Western North America.

ARCH. Geikie

\section{THE ATOMIC THEORY}

The Atomic Theory. By Ad. Wurtz, Membre de 1'Institut, \&c. Translated by E. Cleminshaw, M.A. (London : C. Kegan Paul and Co., 1880.)

$7 \mathrm{HE}$ latest addition to the International Scientific 1 Series is at once a scientific treatise and an artistic work. The translator has very fairly maintained the ciearness and crispness of the French style, whereby the book is marked with a distinct individuality and selfcompleteness.

The sharpness of the impression which this work pro. duces on the mind is gained without making any great sacrifice of accuracy, although it must be confessed there is, in some chapters, a lack of detailed facts, which is against the value of the work as a reference book for the advanced student; and in others there is too free a use of fancy, which faculty is not synonymous with that 